\title{
Health Education Concepts in School Biology Textbooks in the United States and Singapore
}

\author{
Ali Tared Aldossari ${ }^{1 *}$ \\ ${ }^{1}$ Imam Abdulrahman Bin Faisal University (previously known as the University of Dammam), College of Education, Curriculum \& \\ Instruction Department, SAUDI ARABIA
}

Received 9 October 2020 - Accepted 26 March 2021

\begin{abstract}
This study investigates the inclusion of health education concepts in biology textbooks in the United States of America and Singapore. It employs a content analysis methodology to examine biology textbooks, considering the theme as a unit and dividing health concepts into four main fields. The findings for both countries indicate that the field of diseases and epidemics occurred most frequently, followed by disease prevention and treatment, then environment. Finally, food and nutrition occurred least frequently. The overall scores for the textbooks of these two countries, with regard to the inclusion of health concepts, reveal a significant difference in favour of the USA. Based on these findings, the researcher recommends that school textbooks should increase their coverage of health concepts, especially in the fields of the environment and food and nutrition, in order to provide students with more accurate, reliable health information and experiences that are consistent with current needs.
\end{abstract}

Keywords: biology textbooks, health education concepts, secondary stage, USA, Singapore

\section{INTRODUCTION AND THEORETICAL FRAMEWORK}

A characteristic of the third millennium is the integration of knowledge and aspects of real life. This has affected the nature of scientific knowledge itself, especially in the field of health.

Many countries and institutions prioritise human health as the most important aspect of life, both for individuals and for society as a whole. As a result, education related to health and hygiene is essential because it has the potential to provide individuals with ideas, information and behavioural patterns that integrate scientific knowledge with approved health concepts. This will be reflected in the achievement of health education goals, improved emotional, mental and physical strength (Abdulwahed \& Shneif, 2018; Alburdini, 2019) and enhanced happiness and wellbeing (Kolbe, 2019).

Concepts constitute the building blocks of science, as they represent the broadest elements in the components of the human cognitive system; therefore, they form an important base for further educational steps
(Kampourakis, 2018). The learning of concepts is, therefore, a main goal in the learning process. It can help the organisation of experiences, the facilitation of classification, the storing and retrieving of information and the increasing of self-efficacy. It can also allow learning to be applied in new situations, letting individuals build cumulative knowledge and create positive life experiences (Bruner et al., 2009).

Learning health education concepts contributes towards improving necessary health skills and developing healthy behavioural patterns, in addition to the ability to participate in solving health problems and assist in making appropriate health-related decisions (Erdogan et al., 2009). As a result, a positive relationship may develop between health education on the one hand and school and college education on the other (Hahn \& Truman, 2015).

Educational curricula are considered one of the most important means through which individuals become health literate (Svalastog et al., 2017). Because of their widespread use, biology textbooks are at the vanguard of providing students with health concepts and practical applications. Such textbooks address issues that

(c) 2021 by the authors; licensee Modestum. This article is an open access article distributed under the terms and conditions of the Creative Commons Attribution License (http://creativecommons.org/licenses/by/4.0/).

$\square$ ataldossari@iau.edu.sa (*Correspondence) 


\section{Contribution to the literature}

- This study intends to direct the attention of policy makers involved in curricula development and preparation toward a stronger focus on health concepts, especially in times of epidemics and disease.

- It is therefore expected that this study will benefit those in charge of life sciences textbooks by considering health education concepts that may improve students' health-related habits and patterns. Thus, education will be able to move towards educating students about preventive and therapeutic health and develop their levels of health-related wellbeing.

- Furthermore, this study sheds light on the extent to which health education concepts are included in school textbooks. Considering the findings, we recommend a shift in the focus of textbooks.

- The study was worth undertaking because it seeks to inform policy makers about the measures they must put in place when selecting or designing curriculum materials, as these decisions impact what leaners achieve by the end of the learning process. Important insights have been identified regarding how different countries can employ textbooks to indicate the value of health issues. The paper provides important insight into the area of health education, especially in the wake of epidemics, pandemics and rampant misinformation.

- The USA and Singapore were chosen because these two countries are ranked highest in terms of educational policy, particularly in relation to the adoption of projects and initiatives for developing science and mathematics curricula.

contribute to educating students from a health perspective with a view of improving their quality of life and changing their behaviour to promote disease prevention.

\section{THE STUDY PROBLEM AND RESEARCH QUESTIONS}

Many countries have made great efforts to make fundamental changes to their science curricula in order to keep pace with scientific and technological developments and offer global leadership. The United States of America (USA) and the Republic of Singapore have been among the first countries to adopt new scientific projects, directions and initiatives. The projects adopted by the educational systems in the USA include 'Science, Technology and Society' (STS), 'Scope, Sequence, and Coordination' (SS \& C) and 'Trends in Mathematics and Science Study' (TIMSS), while the educational systems in the Republic of Singapore have adopted the 'Schools of Thinking and Educating the Nation' and 'Teach Less, Learn More' initiatives (Gopinathan \& Michael, 2011; Mok, 2008).

In light of the continuous change and development witnessed in the science curricula (including biology) in both the USA and the Republic of Singapore, the researcher explored the extent to which biology textbooks have responded to these developments and the dire need to do so, especially when students are required to understand health concepts that are expected to contribute to healthy living and improve their quality of life in general. This is particularly true during epidemics, where textbooks are required to include new, accurate health concepts to help students to acquire health information and develop healthy trends and behaviour. The spread of disease and low levels of health awareness in any country are due not only to a lack of services but also to the failure to apply health concepts. This refers to how what individuals learn translates into behaviour that helps them to prevent disease, maintain public health and assume responsibility for protecting the health of others (Al-burdini, 2019). Educating students about health concepts may help them to develop and modify their behaviour so that they can deal effectively with health problems. Unhealthy behaviour is often due to a lack of knowledge about healthy habits, experiences and practices (AlRwaythi, 2016). Many studies highlight the inadequacy of life sciences textbooks in dealing with the health concepts necessary for the development of knowledge, attitudes and healthy behaviour of students (Hahn \& Truman, 2015; Kann et al., 2007; Nomoto et al., 2011).

Therefore, this study aims to investigate the extent to which health education concepts are included in biology books in countries that have a scientific and technical tradition of bringing about fundamental changes and reform within their scientific curricula. Because the USA and Singapore rank highly in terms of educational policy, particularly in relation to the adoption of projects and initiatives for developing science and mathematics curricula, this study focuses on textbooks in these countries. The specific focus is on biology textbooks, as they cover health practices and daily life. Such textbooks are extremely important to students and teachers alike in directing educational experiences and building scientific concepts. The main research question is:

To what extent do biology textbooks include health education concepts?

This main question can be further divided into three sub-questions:

1. To what extent do high school biology textbooks in the USA include health education concepts? 
2. To what extent do high school biology textbooks in Singapore include health education concepts?

3. Are the health education concepts included in high school biology textbooks different in the two countries?

\section{Study Objectives}

The objectives of this study are to:

1. Identify the areas of health education concepts expected to be available in the content of school biology books.

2. Determine the extent to which health education concepts are made available to secondary school students in biology textbooks in the USA and Singapore.

3. Compare the content of biology textbooks in the USA and Singapore to determine the extent to which they include health education concepts.

\section{The Importance of the Study}

This study responds to the global interest in health education, especially in times of epidemics and disease, which necessitate concerted efforts to achieve the highest standards of health awareness and disease prevention at both individual and societal levels.

The importance of this study also lies in the need to enrich the educational literature related to health education concepts in life sciences textbooks. Recommendations and proposals may contribute towards increasing the focus on health concepts in biology books and widening the scope for specialists, decision-makers, life sciences book planners, supervisors and teachers to tackle health education concepts in ways that inform students about healthy lifestyle habits and behaviour, in addition to opening the door for researchers to conduct further relevant studies.

\section{METHODOLOGY AND PROCEDURES}

\section{Study Methodology}

The method to be adopted depends mainly on the nature of the study, its variables, assumptions and questions. Denscombe (2008) believes that choice of methodology may be affected by the availability of alternatives.

The researcher used the content analysis methodology to obtain the required theme data, as it was the most appropriate unit of content analysis (Erbaç et al., 2012).

An analytical descriptive approach is an accurate, flexible branch of the descriptive approach, where information or collected observations are processed and interpreted easily to clarifying links, relationships or comparisons between results (Toaima, 2004).
Frequency distribution is a statistical method based on calculating observations or number of occurrences of a specific field or category. These observations are then compared with other related fields and displayed in a frequency table (Toaima, 2004).

The frequency at which health education concepts appeared in the targeted books was calculated. Calculating percentages based on observations/number of frequencies is one of the statistical methods for presenting and interpreting quantitative and qualitative data. This is done by calculating the frequency of observations of a particular field or category, comparing these observations with other related fields, and then displaying them in a frequency distribution table (Toaima, 2004).

This is why the content analysis process includes main headings and sub-headings, written paragraphs, pictures, drawings, activities, experiments, discussions, examples, questions and self-evaluation.

\section{Study Samples}

The study samples were comprised of high school biology books for three grades in each country: tenth to twelfth grade in the USA, and seventh to ninth grade in the secondary stage in Singapore. American and Singaporean books that have been approved by the Secondary Education Authority in the two countries have been chosen whether these are set books or recommended as basic resources and references for students.

The academic content of the American books that were reviewed was limited to biology textbooks prepared for secondary school education, published by Houghton Mifflin Harcourt. Said books contain 34 chapters with a total of 984 pages.

The Singaporean textbooks were intended for use in high school (GCE O-Level) biology classes and published by Marshall Cavendish Education. The books contain 22 chapters with a total of 463 pages.

The study sample was chosen intentionally, for several reasons:

- The USA and the Republic of Singapore witnessed distinguished flexible scientific and technical precedence in reforming and developing their scientific curricula. The targeted books in both countries have been developed recently in response to projects, trends and initiatives, such as the STS project and the SS \& C project in the USA and the initiatives 'Thinking Schools, Learning Nation' and 'Teach less, Learn More' in Singapore.

- The contents of the targeted books in both countries are similar; the titles and topics are almost the same in many study units.

- The students' age groups in both countries are relatively close; in America, it is 16-18 years (with an average age of 17 years), while in Singapore, it 
is 13-17 years (with an average age of 15 years). Students within this range have similar characteristics and traits, especially in the field of conceptual development, as indicated by many studies (Bin AlTaher, 2015; Sadiqi, 2014).

\section{Study Instrument}

The study instrument used is an analysis form designed by the researcher with reference to the global standards for health education concepts. Bybee and Pruitt (2017) mentioned in their book, Perspectives on Science Education, A Leadership Seminar, that standards of health education may differ according to environment, time, programme, goal, target group or the national standards that the state seeks to achieve through school curricula. It is necessary to develop health concepts that are commensurate with the requirements of reality. In the USA, concepts are centred on individual and community health (Bybee \& Pruitt, 2017), while health education in Singapore focuses on four areas: physical health, preventive health, nutritional health and physical exercise (Zhenghua Primary School, 2014).

The study of (Kiviniemi \& Przybyla, 2019) indicated that health education curricula and programmes are based on four components: public health, healthy behaviour, disease and epidemics and environmental health. As for the fields of school health education, according to (Kolbe, 2019), they are multiple and open fields that are chosen and decided according to scientific and environmental developments and educational goals. The most important components of health education programmes focus on health education, physical education, environmental health, nutritional health and psychological and social health.

In light of the above and the relevant theoretical literature, a preliminary list of the areas of health concepts was built. It consists of five fields: prevention and cure, nutrition, environment, disease and epidemics and a mental and psychological domain.

It was presented to four referees in the field of health sciences, curricula and teaching methods. Three referees recommended the removal of the mental and psychological health field due to the difficulty of investigating it in the targeted books. The final list of health concepts is as follows.

\section{Disease prevention and treatment}

This field is reflected in educational content that either presents the procedures and measures followed in the field of public health or refers to quality-of-life issues such as preventing disease (especially infectious diseases); predicting and preventing the spread of disease; early check-ups; body care; sports and biomedical engineering; diagnosing, controlling and treating diseases and complications; and rehabilitation.

\section{Food and nutrition}

This field includes the elements and importance of diet; food groups and nutritional value; methods of preserving foods and drinks; food quality and cleanliness; eating behaviour; and habits, food technology and therapeutic nutrition.

\section{Environment}

This field includes topics that address healthy environments and the integrity of the components of the ecosystem (such as air, water and soil). These include biodiversity; environmental balance and food chains; sources of threat to the ecosystem; environmental management; ethical laws; and hazardous materials management.

\section{Diseases and epidemics}

This field includes topics related to pathogens; infection; pollution; toxins; bacteria; viruses; fungi; vaccines; antibiotics; bioremediation; and treatments for disease.

\section{Validity of the Instrument}

To ensure the validity of the analysis, the researcher's initial survey design, which covered five fields, was reviewed by a number of experienced and specialised professors. Based on their feedback, the researcher adapted the list so that its final form contained four fields of health education concepts, as described above.

\section{Reliability of the Instrument}

The researcher analysed the study samples more than once, and the reliability coefficient between the two analyses was calculated using the following equation (Ott \& Longnecker, 2008):

$$
\begin{gathered}
\text { Agreement percentage }= \\
\frac{\text { no.of agreements between the two analyses }}{\text { no.of agreements }+ \text { no.of disagreements }} \times 100 \%
\end{gathered}
$$

The percentage of agreement between the two analyses was $81 \%$, indicating that the list employed and the analytical method are reliable and that the instrument is appropriate for the purposes of the study.

\section{RESULTS AND DISCUSSION}

\section{To What Extent Do High School Biology Textbooks in the USA Include Health Education Concepts?}

To answer the first question of the study, the frequencies and percentages for USA textbooks were calculated and each field was ranked, as shown in Table 1.

As Table 1 indicates, the total frequency of health education concepts in the content of the American biology books was 362. The field of diseases and 
Table 1. Fields of health education concepts included in high school biology textbooks (USA)

\begin{tabular}{lccc}
\hline Field & Frequency & $\%$ & Rank \\
\hline Disease prevention and treatment & 97 & $26.8 \%$ & 2 \\
Food and nutrition & 31 & $8.6 \%$ & 4 \\
Environment & 84 & $23.2 \%$ & 3 \\
Diseases and epidemics & 150 & $41.4 \%$ & 1 \\
Total & 362 & $100 \%$ & - \\
\hline
\end{tabular}

epidemics appeared most frequently, with a total of 150 iterations ( $41.4 \%$ of all health education concepts). This is a clear indication of the interests of the American biology textbooks, which included chapters on viruses and prokaryotes; protists and fungi; the immune system and disease; nervous and endocrine systems; and respiratory and circulatory systems. This result is consistent with that of Nomoto et al. (2011), who found that textbooks in both the USA and Spain took diseases and epidemics, especially AIDS and sexually transmitted diseases (STDs), most seriously.

This finding differs from other studies, in which the fields of disease and epidemics and physical health in general were found to appear less frequently than other fields. For example, AlRwaythi (2016) found that the field of physical health was ranked third, after environment and prevention. Al-burdini (2019) found that the field of disease was ranked last, after fields of physical and personal health and the environment. Such differences may be attributed to variations in the study samples and environments.

The second most dominant field was disease prevention and treatment, with 97 iterations (26.8\%). This result is at odds with those reported by Ali Saleh et al. (2017), who found that prevention and public health was the least prevalent field (8.4\%), and also Kazemian et al. (2014), who found a decrease in health education concepts related to the prevention field in elementary science books in Iran.

However, the current study tallies with AlRwaythi's (2016) study, which found that the preventive field ranked second $(28.5 \%)$ among the health education fields in elementary stage science books in Saudi Arabia. Additionally, Gilavand et al. (2016) found that science books for the preparatory stage in Iran focused more on the disease prevention and treatment field than other fields $(21.10 \%)$.

The researcher believes that the findings of the current study regarding the frequency of this field are logical because many chapters in the targeted books relate to it (such as 'The Evolution of Populations', 'Human Systems and Homeostasis', 'Nervous and Endocrine Systems', 'Respiratory and Circulatory Systems' and 'Protection, Support, and Movement').

The third most-prevalent field was environment $(\mathrm{n}=$ 84, 23.2\%), with chapters covering 'Ecology', 'Animals', 'Plants', 'Human Impact on Ecosystems' and 'The
Biosphere'. While this finding is similar to that of Ali Saleh et al. (2017), who found that the field of environmental health ranked second in elementary stage science books in Jordan, Tweissi and Alshaweesh (2013) ranked environmental health first in their investigation of health education concepts in science books in Jordan. AlRwaythi (2019), who investigated the inclusion of health education fields in elementary science books in Saudi Arabia, also ranked the environment field in first place $(33.5 \%)$.

It is worth mentioning that several studies highlight the importance of the environment field in terms of health (Ardan et al., 2015; Fančovičová \& Prokop, 2011; Mudrak et al., 2019; Wang et al., 2018).

Concepts related to the food and nutrition field appear least frequently $(n=31,8.6 \%)$. Chapters that cover this field included 'Human Systems and Homeostasis' and 'Digestive and Excretory Systems'. This result is consistent with that of Tweissi and Alshaweesh (2013), who also found that the food field was the least prevalent. This indicates the low representation of this field compared to the other fields in biology textbooks for the secondary stage in the USA. It is also consistent with findings reported by Abdulwahed and Shneif (2018), who investigated the degree to which intermediate stage biology textbooks in Iraq discussed concepts related to food technology and therapeutic nutrition, such as the importance of food; food not medication; food habits; food diversity; nutrition and mental processes; nutrition and tumours; international attitudes; food and colours; and food and public culture. Their overall findings showed a low coverage of food technology and therapeutic nutrition in the targeted textbooks. The findings of the current study are also congruent with those of Kazemian et al. (2014), who discovered a decline in health concepts related to the food field in elementary science textbooks in Iran.

Accordingly, the overall findings of this study in response to the first question are generally in line with the results of similar studies located in a range of countries. These include Al-burdini's (2019) study, which indicates a lack of health education concepts in Islamic science books in Jordan, and the study of Tweissi and AlShawish (2013), which shows a low degree of inclusion of health concepts in primary science books in Jordan. Nomoto et al.'s (2011) investigation of the inclusion of health education concepts in textbooks in America and Spain indicated that $64.3 \%$ of textbooks showed insufficient interest in health education and provided inaccurate or outdated information. Similarly, Kann et al.'s study (2007) found that $35.8 \%$ of secondary schools in America needed to provide students with more accurate information on health education concepts. They found that the main reason for the lack of inclusion of health concepts in textbooks was the failure to seek the help of specialists with the ability and competence to combine scientific knowledge with health awareness. 
Table 2. Fields of health education concepts included in high school biology textbooks (Singapore)

\begin{tabular}{lccc}
\hline Field & Frequency & $\%$ & Rank \\
\hline Disease prevention and treatment & 70 & 23.8 & 2 \\
Food and nutrition & 37 & 12.6 & 4 \\
Environment & 50 & 17 & 3 \\
Diseases and epidemics & 137 & 46.6 & 1 \\
Total & 294 & 100 & - \\
\hline
\end{tabular}

\section{To What Extent Do High School Biology Textbooks in} Singapore Include Health Education Concepts?

To answer the second question of this study, the frequency that concepts related to each field appeared in the Singaporean textbooks was calculated, and each field was then ranked, as shown in Table 2.

As shown in Table 2, 294 iterations of the health education concepts were included in the content of the Singaporean biology textbooks. The field of disease and epidemics was by far the most prevalent $(n=137,46.6 \%)$. This is consistent with findings reported by Nomoto et al. (2011), which stated that science textbooks focused on the field of disease and epidemics, particularly AIDS and STDs. The considerable interest in the concept of disease and epidemics in the targeted books is reflected by the many chapters tackling this field, including 'Cell Structure and Organization', 'Transportation in Humans', 'Respiration in Humans', 'Excretion in Humans' and 'The Human Eye'.

At the same time, this finding differs from those of other studies, where the field of disease and epidemics, and physical health in general, has a low frequency rate compared to other fields. As noted above, AlRwaythi's (2016) study ranks the field of physical health third, after the fields of environment and disease prevention; Alburdini (2019) ranks the field of disease last, after fields of physical and personal health and environment. Such differences may be due to variations in the study samples and the educational goals that regulate the respective educational environments.

In the Singaporean textbooks, the disease prevention and treatment field were the second most prevalent $(\mathrm{n}=$ $70 ; 23.8 \%$ ). This finding is at odds with that of Ali Saleh et al. (2017), who found that the field of prevention and public health was the least prevalent $(8.4 \%)$. It also conflicts with Kazemian et al.'s finding (2014), which stated that the inclusion of health concepts related to prevention was low in elementary textbooks in Iran.

However, the findings of this study with regard to disease prevention and treatment are in line with those of AlRwaythi (2016), who investigated the inclusion of health education fields in elementary science books in Saudi Arabia. It was found that the preventive field had the second-highest frequency, at $28.5 \%$. The current study's findings also align with Gilavand et al.'s (2016), which revealed that science textbooks produced for preparatory stage education in Iran showed more interest in the field of disease prevention and treatment than other fields $(21.1 \%)$.

The high frequency of content related to the disease prevention and treatment field in this study is reflected in the many chapters and units covering it in the targeted Singaporean textbooks. These include 'Diffusion', 'Transportation in Humans', 'Respiration in Humans', 'Excretion in Humans', 'The Nervous System', 'The Human Eye', 'Hormones', 'Reproduction in Humans', 'Heredity' and 'Molecular Genetics'.

The environment field was the third most prevalent ( $\mathrm{n}=50,17 \%$ ), covered by chapters and units including 'Transportation in Plants', 'Reproduction in Plants', 'Ecology' and 'Our Impact on the Ecosystem'. This finding is somewhat similar to that of Ali Saleh et al. (2017), who found that the field of environmental health ranked second among health concepts in elementary stage science books in Jordan; however, this field was ranked first in Tweissi and Al Shawish's (2013) study. Similarly, in AlRwaythi's (2019) study, which investigated the inclusion of health education fields in elementary stage science books in Saudi Arabia, the environment field ranked first $(33.5 \%)$.

The researcher believes that the environment field should have received more attention in the targeted books due to its importance and close relationship with the disease prevention field. Many studies, such as Fančovičová and Prokop's (2011), Ardan et al.'s (2015), Wang et al.'s (2018) and Mudrak et al.'s (2019), have highlighted the importance of including the environment field in textbooks - especially those related to science and biology. This implies that the environment field needs to occupy an advanced position among the health concepts available in these textbooks.

Concepts related to the food and nutrition field appeared least frequently in the Singaporean textbooks ( $\mathrm{n}=37,12.6 \%)$. Relevant chapters included 'Enzymes', 'Nutrition in Humans', 'Nutrition in Plants' and 'Nutrients', which covered topics such as the need for food, water, carbohydrates, fats and proteins. This finding is consistent with Tweissi and Alshaweesh's (2013), whose study found that the food field was also the least prevalent, overall indicating the relatively low representation of this field (compared to others) in secondary stage biology textbooks in Singapore. Our findings also agree with those of Abdulwahed and Shneif (2018), who found a low rate of inclusion of concepts related to food technology and therapeutic nutrition in intermediate biology textbooks in Iraq, and also those of Kazemian et al. (2014), who identified a decline in health concepts related to the food field in primary school science books in Iran.

Accordingly, the overall findings in response to the second question generally agree with those of similar studies regarding the extent to which health concepts are 
Table 3. The results of the chi-squared test comparing the ratios of health concept-related content in school biology textbooks in the USA and Singapore

\begin{tabular}{|c|c|c|c|c|c|c|c|c|c|}
\hline \multirow{2}{*}{ Field } & & \multicolumn{2}{|c|}{ USA } & \multicolumn{2}{|c|}{ Singapore } & \multirow{2}{*}{ Total } & \multirow{2}{*}{$\mathrm{Chi}^{2}$} & \multirow{2}{*}{$\mathrm{df}$} & \multirow{2}{*}{ Sig. } \\
\hline & & Freq. & $\%$ & Freq. & $\%$ & & & & \\
\hline \multirow{2}{*}{$\begin{array}{l}\text { Disease prevention } \\
\text { and treatment }\end{array}$} & Present & 97 & 26.8 & 70 & 23.8 & \multirow{2}{*}{167} & \multirow{2}{*}{4.365} & \multirow{2}{*}{1} & \multirow{2}{*}{0.037} \\
\hline & Expected & 83.5 & 23.6 & & 28.4 & & & & \\
\hline \multirow[t]{2}{*}{ Food and nutrition } & Present & 31 & 8.6 & 37 & 12.6 & \multirow{2}{*}{68} & \multirow{2}{*}{0.529} & \multirow{2}{*}{1} & \multirow{2}{*}{0.467} \\
\hline & Expected & 34 & 9.4 & 34 & 11.56 & & & & \\
\hline \multirow[t]{2}{*}{ Environment } & Present & 84 & 23.2 & 50 & 17 & \multirow{2}{*}{134} & \multirow{2}{*}{8.627} & \multirow{2}{*}{1} & \multirow{2}{*}{0.003} \\
\hline & Expected & 67 & 6.4 & 67 & 22.8 & & & & \\
\hline \multirow{2}{*}{$\begin{array}{l}\text { Disease and } \\
\text { epidemics } \\
\end{array}$} & Present & 150 & 41.4 & 137 & 46.6 & \multirow{2}{*}{287} & \multirow{2}{*}{0.580} & \multirow{2}{*}{1} & \multirow{2}{*}{0.443} \\
\hline & Expected & 143.5 & 39.6 & 143 & 48.8 & & & & \\
\hline \multirow[t]{2}{*}{ Total } & Present & 362 & 100 & 294 & 100 & \multirow{2}{*}{656} & \multirow{2}{*}{7.049} & \multirow{2}{*}{1} & \multirow{2}{*}{0.008} \\
\hline & Expected & 328 & 100 & 328 & 100 & & & & \\
\hline
\end{tabular}

included in science textbooks. Al-burdini (2019) and Tweissi and AlShawish's (2013) studies, for example, indicated low levels of inclusion of health concepts in Islamic science books and primary science books in Jordan, respectively. As stated above, Nomoto et al.'s (2011) study of the inclusion of health concepts in textbooks in America and Spain found that $64.3 \%$ of textbooks showed an insufficient interest in health education and provided inaccurate or outdated information. Similarly, Kann et al. (2007) found that $35.8 \%$ of secondary schools in America needed to provide students with more accurate information regarding health education concepts. As noted above, they found that the main reason for the lack of inclusion of health concepts in textbooks was the failure to seek help from specialists.

\section{Are the Fields of Health Education Concepts Included in High School Biology Textbooks Different in the Two Countries?}

To answer the third question investigated in this study, a chi-squared test was used to compare the ratios of health concept-related content included in the biology textbooks of each country. The results are shown in Table 3.

As shown in Table 3, the chi-squared test indicates that there are no significant differences between the American and Singaporean biology textbooks regarding the fields of food and nutrition and diseases and epidemics. The total number of occurrences of the field of food and nutrition in the American textbooks was 31, compared to 37 in the Singaporean books. In contrast, the field of disease and epidemics was iterated a total of 150 times in the American textbooks and 137 times in the Singaporean ones. Despite a significantly greater number of pages containing content related to these fields in the American textbooks, a sufficient proportion of the content of the Singaporean textbooks was devoted to health concepts in these two areas; thus, there were no significant differences between the frequencies of the two countries.
Table 3 (again, as per the chi-squared test) shows a statistically significant difference $(\alpha \leq 0.05)$ between the total number of occurrences of the four fields in the sample books. This can be attributed to the country variable, which acts in favour of the American textbooks. Overall, there were 362 occurrences in the American textbooks in comparison to 294 occurrences in the Singaporean textbooks. The researcher attributes this difference to the fact that the Singaporean biology books were made up of 22 chapters with a total of 463 pages, while the American books were made up of 34 chapters with a total of 984 pages, i.e., $47 \%$ more pages. This affected the frequency at which health education concepts were found in those books (compared to the Singaporean books). Moreover, the larger number of pages gave those in charge of writing and preparing these books more space to address health-related issues. Furthermore, the American books were intended for students aged 16 to 18 years, while the Singaporean biology books were intended for students aged 13 to 17 years.

The differences between the countries can be considered formal differences governed by educational, developmental, scientific, social and geographical factors, as indicated by Erdogan et al. (2009). The basic principle in the cognitive construction of health education concepts is that they should have an impact on the realities of practical life and a positive link to the development of health care (especially in light of the spread of disease) on both individual and group levels (Bybee, 2006). The spread of disease and low levels of health awareness in some countries are not only due to a lack of preventive and curative health services. They are also exacerbated by a lack of awareness of health education concepts and their realistic applications. What an individual learns must translate into behaviour and methods of group work to enable them to prevent disease, maintain public health and assume responsibility in protecting the health of others (Alburdini, 2019).

However, the observed reality in the USA indicates that, although health education concepts were available 
in the targeted books, they did not lead to noticeable changes towards positive behaviour and trends in daily life.

\section{LIMITATIONS}

This study has a number of limitations. First, the academic content chosen for review was limited to biology textbooks approved by the secondary education authorities in each country, whether these were set books or recommended as basic resources and references for students. In the USA, the sample textbooks were prepared for use in secondary school education and published by Houghton Mifflin Harcourt. The books contain 34 chapters with a total of 984 pages.

The Singaporean textbooks were intended for use in high school (GCE O-Level) biology classes and were published by Marshall Cavendish Education. The books contain 22 chapters with a total of 463 pages.

The term 'health education concepts' refers to a set of ideas, facts, information and experiences related to students' health conditions. In the current study, these concepts were discussed in detail and categorised into four fields: disease prevention and treatment, food and nutrition, environment and, finally, disease and epidemics.

\section{CONCLUSION}

Based on the findings of the current study, it is clear that health education concepts were often presented in the targeted books in the form of scientific facts and concepts without teaching real life applications. The books therefore failed to address numerous issues: the prevention of infectious diseases and ways to limit their spread; smoking and drugs; sexual and reproductive health; psychological and mental health; traffic accidents; weapons and violence; safety measures at home and at school; methods for preserving food and nutrition-related issues such as anaemia; obesity; weight loss; and loss of appetite. Therefore, it is of the utmost importance that secondary stage textbooks and other textbooks include a wider coverage of health concepts, especially in the fields of environment and food and nutrition, which were found to have low rates of inclusion compared to the fields of disease prevention and treatment and disease and epidemics.

It is also important to hold seminars to enable biology teachers to discuss health education issues and health concepts. Moreover, to promote the importance of understanding necessary health concepts, guides must be prepared for science and biology teachers with accurate information on health concepts, especially on emerging issues. The development process for textbooks should be subject to revision according to the health issues that need to be addressed for students in order to meet the needs and aspirations of contemporary society.
These health concepts and issues must be integrated into the learning and teaching process, which may raise awareness of the importance of health education.

In light of the results, this study offers the following suggestions:

1. Studies that are similar and relevant to the current study should be conducted to investigate the extent to which health concepts are included in other curricula, books and courses at school and university levels. This applied particularly to natural sciences and biology books, as such books and courses are highly relevant to health education.

2. Interactive seminars and training courses that bring together biology teachers and specialists in relevant scientific fields should be held so that they may discuss health-related issues, especially emerging ones. Additionally, international standards for health concepts should be integrated into teacher training programmes to contribute to the effective teaching of such concepts.

3. The extent and accuracy of biology teachers' knowledge of health education concepts should be regularly checked.

4. Specialists in health education fields should be involved in writing biology books.

5. Studies should be conducted to investigate the extent to which students acquire health education concepts and the degree to which biology teachers possess sound and accurate knowledge of health education concepts.

Author contributions: All authors have sufficiently contributed to the study, and agreed with the results and conclusions.

Funding: No funding source is reported for this study.

Declaration of interest: No conflict of interest is declared by authors.

\section{REFERENCES}

Abdulwahed, A., \& Shneif, M. (2018). Food technology and therapeutic nutrition in the biology textbooks of the intermediate stage. Eurasia Journal of Mathematics, Science and Technology Education, 14(12), em1645. https:// doi.org/10.29333/ ejmste/ 97836

Al-burdini, S. (2019). The health concepts included in the books of Islamic education for the ninth and tenth grades in Jordan. Journal of Educational and Psychological Sciences, 3(29), 87-102. https:/ / doi.org /10.26389/AJSRP.S120319

Alfqy, M., et al. (2020). Repercussions of the pandemic: Analytical and critical insights into the implications of the Corona pandemic 2020. Center for Strategic Studies; Bibliotheca Alexandrina. 
Ali Saleh, R. S. A., Alrsa'i, M., \& Alhelalat, K. (2017). The degree of the incorporating of health concepts in science textbooks for the first three grades in Jordan according to international standards. Dirasat: Educational Sciences, 44(2), 40-57. https://doi.org/ $10.12816 / 0040649$

Al-Qarni, H. S. (2016). The extent of benefiting from science books in the primary stage in the Kingdom of Saudi Arabia during the past 45 years (1391$1436 \mathrm{H})$ in terms of health and safety topics. Journal of Educational Sciences, Prince Sattam University, 1(2), 107-124.

AlRwaythi, E. (2016). Health education in science textbooks for the three higher grades in the elementary school in the Kingdom of Saudi Arabia. Studies in Curricula and Teaching Methods, Ain-Shams University, (214), 15-90.

Ardan, A., Ardi, M., Hala, Y., Supu, A., \& Dirawan, G. (2015). Needs assessment to development of biology textbook for high school class X-based the local wisdom of Timor. International Education Studies, 8(4), 52-59. https://doi.org/10.5539/ ies.v8n4p52

Bayda, N. I., \& Sutliff, G. (2020). Comparing Extracted and Stipulated Definitions in Algebra 1 Textbooks and Khan Academy. International Electronic Journal of Mathematics Education, 15(2), em0579. https:/ / doi.org/10.29333/iejme/7601

Bin AlTaher, T. (2015). Graphic mental representation according to the theory of Jean Piaget. Social Sciences Journal, (11), 169-187. https://doi.org/ $10.12816 / 0012080$

Bruner, J., Goodnow, J., \& Austin, G. (2009). A study of thinking (6th Edn.). Brunswick.

Bybee, R. (2006). The National Science Education Standards: Personal reflections. School Science and Mathematics, 106(2), 57-63. https:/ / doi.org/10.1111 /j.1949-8594.2006.tb18135.x

Bybee, R., \& Pruitt, S. (2017). Perspectives on science education: A leadership seminar. NSTA Press.

Choy, B. H., Lee, M. Y., \& Mizzi, A. (2020). Insights into the Teaching of Gradient from an Exploratory Study of Mathematics Textbooks from Germany, Singapore, and South Korea. International Electronic Journal of Mathematics Education, 15(3), em0592. https:// doi.org/10.29333/iejme/8273

Contel, T. M., Ferrandis, I. G., \& Ferrandis, X. G. (2016). Light pollution in natural science textbooks in Spanish secondary education. European Journal of Science and Mathematics Education, 4(2), 129-139. https://doi.org/10.30935/scimath/9459

Denscombe, M. (2008). Communities of practice: a research paradigm for the mixed methods approach. Communities of practice: a research paradigm for the mixed methods approach. Journal of Mixed Methods Research, 2(3), 270-283. https:/ / doi.org/10.1177/1558689808316807

Erdogan, M., Kostova, Z., \& Marcinkowski, T. (2009). Components of environmental literacy in elementary science education curriculum in Bulgaria and Turkey. Eurasia Journal of Mathematics, Science and Technology Education, 5(1), 15-26. https:/ / doi.org/10.12973/ejmste/75253

Fančovičová, J., \& Prokop, P. (2011). Children's ability to recognise toxic and non-toxic fruits. Eurasia Journal of Mathematics, Science E Technology Education, 7(2), 115-120. https:/ / doi.org/10.12973/ ejmste/75186

Gilavand, A., Moosavi, A., Gilavand, M., \& Moosavi, Z. (2016). Content analysis of the science textbooks of Iranian junior high school course in terms of the components of health education. International Journal of Pediatrics, 4(12), 4057-4069. https:/ / doi.org/10.22038/ijp.2016.7428

Gopinathan, S., \& Lee, M. H. (2011). Challenging and coopting globalization: Singapore's strategies in higher education. Journal of Higher Education Policy and Management, 33(3), 287-299. https://doi.org/ 10.1080/1360080X.2011.565001

Hahn, R., \& Truman, B. I. (2015). Education improves public health and promotes health equity. International Journal of Health Services, 45(4), 657-678. https:/ / doi.org/10.1177/0020731415585986

Ikeda, M., \& Yamamoto, M. (2021). Ideology in Science Textbooks for Japanese Students in East Asian Colonies: Focusing on Plant Species that Appear in Manchuria Textbooks. Eurasia Journal of Mathematics, Science and Technology Education, 17(3), em1947. https:/ / doi.org/10.29333/ejmste/9757

Kampourakis, K. (2018). On the meaning of concepts in science education. Science E Education, 27, 591-592. https:/ / doi.org/10.1007/s11191-018-0004-x

Kann, L., Telljohann, S., \& Wooley, S. (2007). Health education: Results from the School Health Policies and Programs Study 2006. Journal of School Health, 77(8), 408-434. https://doi.org/10.1111/j.17461561.2007.00228.x

Kazemian, R., Ghasemi, H., Movahhed, T., \& Kazemian, A. (2014). Health education in primary school textbooks in Iran in school year 2010-2011. Journal of Dentistry, 11(5), 536-544. https: / / www.ncbi.nlm. nih.gov/pmc/articles/PMC4290773/

Kepceoglu, I., \& Karadeniz, S. (2017). Analysis of analogies in Turkish elementary mathematics textbooks. European Journal of Science and Mathematics Education, 5(4), 355-364.

Khine, M. S., \& Liu, Y. (2017). Descriptive Analysis of the Graphic Representations of Science Textbooks. European Journal of STEM Education, 2(3), 06. https://doi.org/10.20897/ ejsteme/81285 
Kiviniemi, M., \& Przybyla, S. (2019). Integrative approaches to the undergraduate public health major curriculum: Strengths, challenges, and examples. Frontiers in Public Health, 7, 106. https:/ / doi.org/10.3389/fpubh.2019.00106

Kolbe, L. J. (2019). School health as a strategy to improve both public health and education. Annual Review of Public Health, 40, 443-463. https:/ / doi.org/10.1146/ annurev-publhealth-040218-043727

Mok, K. H. (2008) Varieties of regulatory regimes in Asia: The liberalization of the higher education market and changing governance in Hong Kong, Singapore and Malaysia. Journal of the Pacific Review, 21(2), 147-170. https://doi.org/10.1080/ 09512740801990220

Mudrak, O., Mazur, G. F., Herasymiuk, K. H., Mudrak, H., \& Tarasenko, H. (2019). Environmental management of protected objects of the Eastern Podillya: Theory and practice. Ukrainian Journal of Ecology, 9(4), 732-737. https://doi.org/10.15421/ 2019_819

Nomoto, M., Nonaka, D., Mizoue, T., Kobayashi, J., \& Jimba, M. (2011). Content analysis of school textbooks on health topics: A systematic review. BioScience Trends, 5(2), 61-68. https://doi.org/ 10.5582/bst.2011.v5.2.61

Ott, L., \& Longnecker, M. (2008). An introduction to statistical methods and data analysis (6th ed.). DUXBURY (Wadsworth Group), Forest Lodge Road Pacific Grove, USA.

Sadiqi, R. (2014). The development of mathematical concepts in the child according to the theory of Jean Piaget. Journal of Psychological and Educational Studies, (12),143-150.
Stasinakis, P. K. (2021). Analysis of Greek Textbooks about Marine Biology. Interdisciplinary Journal of Environmental and Science Education, 17(2), e2234. https://doi.org/10.21601/ijese/9336

Svalastog, A. L., Donev, D., Kristoffersen, N. J., \& Gajović, S. (2017). Concepts and definitions of health and health-related values in the knowledge landscapes of the digital society. Croatian Medical Journal, 58(6), 431-435. https://doi.org/10.3325/ cmj.2017.58.431

Toaima, R. (2004). Teaching content in the humanities. Dar Al Fikr Al Arabi.

Tweissi, A., \& Alshaweesh, E. (2013). Health concepts included in science textbooks of the sixth and seventh grade in Jordan. The Educational Journal, 27(108), 253-287. https://www.researchgate.net/ publication/281279413_Health_Concepts_include d_in_Science_Textbooks_of_the_Sixth_and_Sevent h_Grade_in_Jordan

Upahi, J. E., \& Jimoh, M. (2016). Classification of end-ofchapter questions in senior school chemistry textbooks used in Nigeria. European Journal of Science and Mathematics Education, 4(1), 90-102. https://doi.org/10.30935/scimath/9456

Wang, H. H., Hong, Z. H., Liu, S. C., \& Lin, H. S. (2018). The impact of socio-scientific issue discussions on student environmentalism. Eurasia Journal of Mathematics, Science and Technology Education, 14(12), 1-15. https://doi.org/10.29333/ejmste/ 95134

Zhenghua Primary School. (2014). Singapore Education Landscape Overview. https://zhenghuapri.moe. edu.sg/zhenghua-journey

\section{http://www.ejmste.com}

